\title{
PEMBENTUKAN KEPRIBADIAN MUSLIM DENGAN TARBIYAH ISLAMIYAH
}

\author{
Saifurrahman \\ Sekolah Tinggi Ilmu Tarbiyah Raudhatul Ulum, Sakatiga \\ Email: shafarahman56@gmail.com
}

\begin{abstract}
Abstrak
Kepribadian Muslim adalah kepribadian yang pandangan, sikap, pilihan, keputusan, dan perbuatannya sesuai dengan nilai-nilai Islam. Pembentukan Kepribadian Muslim adalah suatu usaha untuk membentuk kepribadian seseorang agar sesuai dengan aqidah dan nilai-nilai Islam. Hal ini sangat penting dilakukan, mengingat kerusakan moral semakin banyak terjadi, padahal mayoritas masyarakat kita beragama Islam, yaitu agama yang dikenal sangat menjunjung tinggi moralitas. Tulisan ini secara garis besar menjelaskan bahwa terdapat sebuah konsep dalam Pembentukan Kepribadian Muslim, yaitu Tarbiyah Islamiyah. Ia merupakan pemikiran, pendapat atau rancangan mengenai cara ideal dalam berinteraksi dengan fitrah manusia untuk memproses perubahan dalam dirinya menuju kondisi yang lebih baik. Secara operasional konsep ini meliputi aspek perbaikan, pembentukan dan penjagaan. Melibatkan diri sendiri dan orang-orang lain. Meliputi aspek akal, fisik dan ruh. Sebagai sarana utama untuk mewujudkan kehidupan pribadi, keluarga dan masyarakat terbaik, sesuai dengan nilai-nilai Islam.
\end{abstract}

Kata Kunci: Kepribadian, Muslim

\section{Pendahuluan}

Kepribadian adalah perwujudan dari pola pikir (yakni bagaimana seseorang berpikir), pola sikap (bagaimana ia bersikap) dan pola tingkah laku (bagaimana ia bertingkah laku). Kepribadian sebenarnya adalah campuran dari hal-hal yang bersifat psikologis (kejiwaan) dan juga yang bersifat fisik. Ia mewakili karakteristik individu yang terdiri dari pola-pola pikiran, perasaan dan perilaku yang konsisten.

Jika dihubungkan dengan Islam, maka Kepribadian Muslim merupakan sinergi antara pola pikir dan pola sikap seseorang yang dilandasi oleh akidah dan nilai-nilai Islam. Dengan kata lain, Kepribadian Muslim adalah kepribadian yang pandangan, sikap, pilihan, keputusan, dan perbuatannya sesuai dengan nilai-nilai Islam.

Pembentukan Kepribadian Muslim saat ini sangatlah penting untuk dilakukan, mengingat mayoritas masyarakat kita beragama Islam dan bangsa kita sedang membangun manusia seutuhnya, sementara bangsa kita saat ini sedang mengalami krisis kepribadian, hal ini ditandai dengan banyaknya kerusakan moral, diantara bentuknya adalah masih banyaknya pornografi, pornoaksi, penggunaan obat terlarang, pemalsuan obat-obatan, pembunuhan, perampokan, anarkisme, perkelahian, Kekerasan Dalam 


\section{Pembentukan Kepribadian Muslim Dengan Tarbiyah Islamiyah Saifurrahman}

Rumah Tangga, penyalah gunaan jabatan, korupsi, dan masih banyak lagi yang lainnya. Hampir setiap hari kita disuguhi berita-berita tentang hal-hal seperti itu. Padahal hal ini sangat bertentangan dengan Kepribadian Muslim, yang sudah seharusnya dimiliki oleh setiap orang yang beragama Islam.

\section{Makna Kepribadian}

Kepribadian atau personality berasal dari bahasa Latin persona yang berarti topeng atau kedok. Yaitu tutup muka yang biasa dipakai oleh pemain-pemain panggung, untuk menggambarkan prilaku, watak atau pribadi seseorang (Sujanto, Lubis dan Hadi 2001). Ada pula yang mengatakan kepribadian berasal dari bahasa latin persum yang berarti wajah yang sesungguhnya (Rab 2008). Dalam ilmu jiwa, kajian kepribadian lebih banyak menyangkut wajah sebenarnya, yang berada di balik topeng. Secara psikologis kepribadian adalah intisari kejiwaan seseorang, atau dengan kata lain sebagai suatu interaksi biologis dengan budayanya, sehingga memberikan corak pada tingkah laku seseorang, sikap-sikap, cara, dan pikiran, sebagai fenomena yang tampak dari aktifitas kejiwaan dan penyesuain dengan kemampuan.

Beberapa ahli mendefinisikan kepribadian secara berfariasi, namun dengan inti yang relatif sama. Menurut Fuad (2006) kepribadian adalah perwujudan dari pola sikap/pola pikir (yakni bagaimana ia bersikap dan berpikir) dan pola tingkah laku (bagaimana ia bertingkah laku). Ia menegaskan bahwa sesungguhnya kepribadian bukanlah dinilai dari nilai-nilai fisik pada diri seseorang (cantik/tidak, kaya/miskin, dan sebagainya) juga bukan pada asal daerah, kebiasaan atau keturunannya.

Allport (dalam RBP 2008), mengatakan bahwa kepribadian adalah sebuah organisasi dinamis di dalam sistem psikis dan fisik individu yang menentukan karakteristik perilaku dan pikirannya. Sedangkan Pervin dan John mengatakan bahwa kepribadian mewakili karakteristik individu yang terdiri dari pola-pola pikiran, perasaan dan perilaku yang konsisten.

Menurut Gunadi (2008) kepribadian adalah ciri atau karakteristik atau gaya atau sifat-sifat khas diri kita yang bersumber dari bentukan-bentukan yang kita terima dari lingkungan, misalnya, keluarga pada masa kecil kita dan juga bawaan-bawaan kita sejak lahir.

Honigman (dalam Rab 2008) menitik beratkan kepribadian pada tindakantindakan, pikiran-pikiran, dan perasaan yang menentukan keunikan individu. Sedangkan Firdaus (2007) mendefinisikan kepribadian sebagai gabungan emosi, perilaku, intelektual dan spiritual manusia.

Dari pendapat-pendapat di atas diketahui bahwa kepribadian itu sebenarnya adalah campuran dari hal-hal yang bersifat psikologis kejiwaan dan juga yang bersifat fisik. kepribadian mewakili karakteristik individu yang terdiri dari pola-pola pikiran, perasaan dan perilaku yang konsisten, yang terbentuk dari faktor lingkungan dan dan faktor bawaan sejak lahir.

Kepribadian seseorang dapat digolongkan ke dalam beberapa golongan. Galen (dalam Adin 2007) menyatakan bahwa kepribadian manusia bisa dibagi menjadi empat 
Volume 1 Nomor 1 Edisi Juni 2016

P-ISSN : 2541-3686

kelompok besar, yaitu sanguin, koleris, melankolis, dan phlegmatis. Meski teori ini tergolong sangat kuno, para psikolog masa sekarang mengakui bahwa teori kepribadian ini banyak benarnya.

Tipe pertama sanguin, orang tipe ini mempunyai banyak kekuatan, bersemangat, mempunyai gairah hidup, bisa membuat lingkungannya gembira, senang. Tapi kelemahannya adalah cenderung bertindak sesuai emosinya atau keinginannya. Jadi orang dengan kepribadian ini mudah sekali dipengaruhi oleh lingkungannya dan rangsangan-rangsangan dari luar dirinya. Dia kurang bisa menguasai diri atau penguasaan dirinya lemah. Orang-orang sanguin cenderung mudah jatuh ke dalam cobaan, karena godaan dari luar bisa begitu memikatnya, dan dia bisa masuk terperosok ke dalamnya.

Tipe kedua adalah koleris, seorang koleris berorientasi pada pekerjaan, dan pada tugas. Dia adalah seseorang yang mempunyai disiplin kerja yang sangat tinggi. Kelebihannya adalah dia bisa melaksanakan tugas dengan setia dan bertanggung jawab dengan tugas yang diembannya. Kelemahan orang dengan tipe ini adalah kemampuannya untuk bisa merasakan perasaan orang lain agak kurang, belas kasihannya terhadap penderitaan orang lain juga agak minim, karena perasaannya kurang bermain.

Tipe ketiga adalah melankolis. Orang tipe ini adalah orang yang terobsesi dengan karya yang paling bagus, yang paling sempurna, mengerti estetika keindahan hidup ini dan perasaannya sangat kuat, sangat sensitif. Kelemahan orang tipe ini adalah mudah sekali dikuasai oleh perasaan dan cukup sering perasaan yang mendasari hidupnya sehari-hari adalah perasaan yang murung. Tidak mudah baginya untuk terangkat, untuk senang, atau tertawa terbahak-bahak. Karenanya, orang melanklolis sering kecewa dan depresi jika apa yang diharapkannya tidak sempurna.

Tipe keempat adalah phlegmatis, orang tipe ini adalah orang yang cenderung tenang dan dari luar cenderung tidak beremosi. Dia tidak menampakkan emosi, misalnya, sedih atau senang. Jadi naik turun emosinya tidak nampak dengan jelas. Orang ini cenderung bisa menguasai dirinya dengan cukup baik dan introspektif sekali, memikirkan ke dalam, bisa melihat, menatap dan memikirkan masalah-masalah yang terjadi di sekitarnya. Jadi dia adalah seorang pengamat yang kuat, penonton yang tajam dan juga seorang pengkritik yang berbobot. Kelemahannya adalah cenderung mau ambil mudahnya, tidak mau susah. Kelemahannya ini membuat dia jadi orang yang kurang mau berkorban bagi yang lain. Orang phlegmatis tak suka keramaian ataupun banyak bicara. Namun, ia banyak akal dan bisa mengucapkan kata yang tepat di saat yang tepat, sehingga cocok menjadi negosiator.

Setiap orang mempunyai kombinasi dari dua kepribadian. Umumnya salah satunya lebih dominan, kadang juga keduanya seimbang. Kepribadian seseorang memang bisa dirubah sedikit demi sedikit setelah tumbuh dewasa. Misalnya, jika ia merasa terlalu emosional, ia bisa merubahnya sedikit demi sedikit sehingga bisa lebih sabar. Namun kepribadian seseorang telah ada sejak ia lahir, dan akan mempengaruhi cara berpikir dan bertindak dalam kehidupannya. 


\section{Pembentukan Kepribadian Muslim Dengan Tarbiyah Islamiyah Saifurrahman}

\section{Aspek-Aspek Kepribadian}

Para ahli menjelaskan kepribadian ke dalam beberapa aspek. Menurut Klages (dalam Suryabrata 2002) aspek kepribadian ada tiga, yaitu materi, struktur dan kualitas. Materi berisi semua kemampuan bawaan beserta keistimewaan-keistimewaannya. Merupakan modal pertama yang disediakan oleh Sang Pencipta untuk dipergunakan dan dikembangkan oleh manusia. Struktur, bila materi dipandang sebagai isi maka struktur dipandang sebagai sifat-sifat bentuknya. Kualitas (sistem dorong-dorongan), antara kemauan dan perasaan terjadi perlawanan yang dalam. Perlawanan ini yang menjadi dasar dari sistem dorong-dorongan.

Berbeda dengan Klages, menurut Freud, aspek-aspek kepribadian ada tiga. Id (aspek biologis), Ego (aspek psikologis) dan Super Ego (aspek sosiologis). Ketiga aspek ini saling berhubungan. Sehingga sukar memisah-misahkan pengaruhnya terhadap tingkah laku manusia. Tingkah laku manusia merupakan hasil dari perpaduan ketiga aspek itu (Suryabrata 2002). Id, berisikan hal-hal yang dibawa sejak lahir (unsur-unsur biologis), termasuk instink-instink. Ia merupakan dunia batin atau subyektif manusia dan tidak mempunyai hubungan langsung dengan dunia obyektif. Ego, timbul karena kebutuhan organisme untuk berhubungan secara baik dengan dunia kenyataan (seperti orang lapar perlu makan). Ia dipandang sebagai ekskutif kepribadian, ia mengontrol jalan-jalan yang ditempuh, memilih kebutuhan-kebutuhan yang dapat dipenuhi dan cara memenuhinya serta memilih obyek-obyek yang dapat memenuhi kebutuhan. Super Ego, merupakan kesempurnaan daripada kesenangan, dapat pula dianggap sebagai aspek moral kepribadian. Fungsi pokoknya ialah menentukan apakah sesuatu benar atau salah, pantas atau tidak, susila atau asusila.

\section{Faktor-Faktor Yang Mempengaruhi Perkembangan Kepribadian}

Allah SWT. telah menghendaki untuk menciptakan manusia dengan proses yang panjang. Berawal dari saripati (berasal) dari tanah, menjadi air mani, kemudian menjadi sesuatu yang melekat, berikutnya menjadi segumpal daging, lalu menjadi tulang belulang, kemudian dibungkus tulang belulang itu dengan daging. Setelah itu dijadikan makhluk yang (berbentuk) lain. Selanjutnya dimatikan dan dibangkitkan kembali pada hari kiamat (QS. Al Mukminuun: 12-16). Ditegaskan pula bahwa proses hidup manusia berawal dari keadaan lemah, menjadi kuat, kemudian lemah kembali dan beruban (QS. Ar Ruum: 54).

Dengan dasar ini, dapat diyakini bahwa kepribadian manusia dapat berubah, itu berarti bahwa kepribadian manusia itu dapat dipengaruhi oleh sesuatu dan dibentuk, karena itu ada usaha-usaha untuk membentuk kepribadian dan membinanya. Secara umum perkembangan dalam diri manusia selalu dipengaruhi oleh dua faktor, yaitu faktor dalam (indogen) dan faktor luar (eksogen) (Sujanto 1996). Perkembangan manusia terjadi di sepanjang kehidupannya, sejak berwujud embrio di dalam rahim sampai menjadi tua dan renta. Hanya saja sifat dan kaulitas perkembangan yang terjadi pada dirinya berbeda-beda, sesuai dengan fase-fasenya. 
P-ISSN : 2541-3686

Abraham (2005, hlm. 2) mengatakan bahwa ada dua hal yang mempengaruhi pembentukan dan perkembangan kepribadian seseorang, yaitu sifat bawaan dan lingkungan berinteraksi. Hal ini diperkuat oleh Mubarok (2007) yang mengatakan bahwa kepribadian seseorang disamping bermodal kapasitas fitrah bawaan sejak lahir dari warisan genetika orang tuanya, ia terbentuk melalui proses panjang riwayat hidupnya, proses internalisasi nilai pengetahuan dan pengalaman dalam dirinya.

Menurut Matta (2008), ada dua faktor yang membentuk kepribadian seseorang, yaitu faktor internal dan eksternal. Faktor Internal adalah kumpulan dari unsur-unsur kepribadian yang secara simultan mempengaruhi perilaku manusia, yaitu Instink Biologis, Kebutuhan psikologis dan Pikiran; Faktor Eksternal adalah faktor-faktor yang berada diluar diri manusia namun secara langsung mempengaruhi perilaku, yaitu lingkungan keluarga, lingkungan sosial dan lingkungan pendidikan.

Suryabrata (2002) mengatakan bahwa sejak dahulu sudah disepakati bahwa pribadi seseorang tumbuh atas dua kekuatan, yaitu kekuatan dari dalam (yang sudah dibawa sejak lahir) dan kekuatan dari luar. KH. Dewantara menyebut dua faktor tersebut sebagai faktor dasar dan faktor ajar. Yang belum disepakati adalah faktor manakah yang lebih kuat dari keduanya tersebut.

Aliran nativisme yang dipelopori oleh Schoupenhouer berpendapat bahwa faktor dari dalam lebih kuat dari faktor dari luar. Dalam kehidupan dapat dilihat adanya orang yang hidup dengan bakatnya, yang dibawa sejak lahir, yang sukar sekali dihilangkan dengan pengaruh apapun juga. Aliran Empirisme yang dipelopori oleh John Locke, berpendapat bahwa faktor dari luar lebih kuat dari faktor dari dalam. Aliran ini dikenal dengan teori tabula rasa, yang menyatakan bahwa anak sejak lahir bersih seperti tabula rasa dan baru akan dapat berisi bila menerima sesuatu dari luar melelui alat inderanya.

Aliran Convergensi (perpaduan) yang dipelopori oleh W. Stern, berpendapat bahwa kedua kekuatan itu sebenarnya berpadu menjadi satu, keduanya saling memberi pengaruh. Bakat yang ada pada seseorang tidak akan berkembang jika tidak dipengaruhi oleh segala sesuatu yang ada di lingkungannya. Begitu pula lingkungan, tidak akan berpengaruh jika tidak ada yang menanggapi di dalam jiwa manusia.

Adapun yang termasuk faktor dari dalam ialah segala sesuatu yang telah dibawa oleh anak sejak lahir, baik yang bersifat kejiwaan (fikiran, perasaan, kemauan, fantasi, ingatan, dll.), maupun yang bersifat jasmani (panjang pedeknya leher, besar kecilnya tengkorak, susunan urat syaraf, otot-otot, keadaan tulang-tulang, dan lain-lain). Sedangkan yang termasuk faktor dari luar ialah segala sesuatu yang ada di luar manusia, baik yang hidup maupun yang mati, berupa tumbuh-tumbuhan, binatang, manusia maupun benda-benda yang ada. Kesemuanya itu ikut serta membentuk pribadi seseorang yang berada di lingkungan itu. Dengan demikian dapat diketahui bagaimana kompleksnya perkembangan pribadi itu dan bagaimana uniknya pribadi itu, tidak ada pribadi yang satu yang benar-benar identik dengan pribadi yang lain.

Adapun hakikat perkembangan kepribadian adalah perubahan-perubahan tingkah laku. Menurut Lewin (dalam Suryabrata 2002) perubahan-perubahan tingkah laku meliputi: perubahan dalam variasi tingkah laku; perubahan dalam organisasi dan 


\section{Pembentukan Kepribadian Muslim Dengan Tarbiyah Islamiyah Saifurrahman}

struktur tingkah laku; bertambah luasnya arena aktivitas; perubahan dalam taraf realitas; dan makin terkoordinasinya tingkah laku.

\section{Kepribadian Muslim}

Kepribadian, dalam bahasa Arab disebut dengan syakhshiyah dan Kepribadian Muslim dengan Syakhshiyah Al-Muslim. Merupakan istilah baru yang tidak ada dalam AlQur'an maupun As-Sunnah. Menurut Fuad (2006), hal itu adalah hal yang lumrah karena tema tersebut merupakan tema baru yang belum pernah ada pada masa Rasulullah SAW, shahabat bahkan pada berabad-abad terwujudnya masyarakat Islam secara nyata. Namun ketika berbagai produk budaya Barat makin merajalela di berbagai negeri kaum Muslimin saat ini; baik produk-produk materi (al-maadiyah) maupun nilai-nilai (al-afkaar); maka pembahasan tema tersebut menjadi sangat penting dibicarakan dan dibahas.

Kepribadian Muslim menurut Marimba (dalam Uhbiyati 1998, hlm. 9) adalah kepribadian yang memiliki nilai-nilai agama Islam, memilih, memutuskan dan berbuat berdasarkan nilai-nilai Islam, dan bertanggung jawab sesuai dengan nilai-nilai Islam. Sedangkan Husna (2007) menyatakan bahwa Kepribadian Muslim merupakan sinergi antara pola pikir dan pola sikap seorang muslim yang dilandasi oleh akidah dan nilainilai Islam. Menurut Mubarok (2007) seseorang disebut memiliki Kepribadian Muslim manakala ia dalam mempersepsi sesuatu, dalam bersikap terhadap sesuatu dan dalam melakukan sesuatu dikendalikan oleh pandangan hidup muslim.

Dari pendapat-pendapat di atas dapat disimpulkan bahwa Kepribadian Muslim adalah kepribadian yang pandangan, sikap, pilihan, keputusan, dan perbuatannya sesuai dengan nilai-nilai Islam.

\section{Unsur-Unsur Kepribadian Muslim}

Allah menciptakan manusia dalam dua tahapan, pertama menciptakan jasadnya, kemudian meniupkan ruh ke dalam jasad itu (QS. 38:72) "Maka apabila aku telah menyempurnakan (penciptaan jasad) nya, lalu kutiupkan ruh-Ku kedalamnya, maka bersujudlah kamu sekalian kepadanya". Dengan landasan ini, menurut Matta (2008) manusia adalah zat yang terdiri dari "segenggam tanah dan setiup ruh". Maka inilah dua unsur utama dalam kepribadian manusia; unsur materi yaitu fisik manusia, dan unsur ruh yaitu hati dan jiwa manusia. Dan itulah tahapan pertama dari proses penciptaan manusia. lalu berdasarkan kedua unsur itu tadi, Allah SWT menciptakan kecenderungan dan dorongan tertentu yang kemudian menjadi dasar-dasar yang membentuk kepribadian manusia. Maka dari unsur ruh itu Allah SWT menciptakan kecenderungan fitrah kepada ibadah; yaitu kecenderungan untuk bertuhan atau menyembah tuhan. Lalu dari unsur fisik itu Allah menciptakan kecenderungan dan dorongan untuk bertindak dan bersikap.

Al Banna (1992, hlm. 359) meletakkan pembentukan Kepribadian Muslim di urutan pertama dalam urutan amal dalam berdakwah. Peribadi dimaksud adalah pribadi yang memiliki aqidah (keyakinan) yang lurus, ibadah yang benar, akhlak mulia, wawasan yang luas, fisik yang kuat, bersungguh-sungguh melawan hawa nafsunya, menjaga waktunya, 
Volume 1 Nomor 1 Edisi Juni 2016

P-ISSN : 2541-3686

mengatur urusannya, punya kemampuan usaha (ekonomi), dan bermanfaat bagi orang lain.

Tim Dakwatuna (2007) menjelaskan unsur-unsur kepribadian yang telah disebutkan Al Banna tersebut. Pertama, Salimul 'Aqidah (Aqidah yang lurus). Salimul aqidah merupakan sesuatu yang harus ada pada setiap muslim. Dengan aqidah yang lurus, seorang muslim akan memiliki ikatan yang kuat kepada Allah, tidak akan menyimpang dari ketentuan-ketentuan-Nya, dan menyerahkan segala perbuatannya kepada Allah semata-mata. Kedua, Shahihul Ibadah (ibadah yang benar). Dalam melaksanakan setiap peribadatan haruslah mengikuti (ittiba') kepada sunnah Rasul SAW yang berarti tidak boleh ditambah-tambahi atau dikurang-kurangi. Ketiga, Matinul Khuluq (akhlak yang kokoh). Merupakan sikap dan perilaku yang harus dimiliki oleh setiap muslim, baik dalam hubungannya kepada Allah maupun dengan makhluk2-Nya. Dengan akhlak yang mulia, manusia akan bahagia dalam hidupnya, baik di dunia apalagi di akhirat.

Keempat, Mutsaqqoful Fikri (wawasan yg luas). Seorang muslim harus memiliki wawasan keislaman dan keilmuan yang luas. Untuk mencapai wawasan yg luas maka manusia dituntut utk mencari/menuntut ilmu. Kelima, Qowiyyul Jismi (jasmani yg kuat). Seorang muslim haruslah memiliki daya tahan tubuh sehingga dapat melaksanakan ajaran Islam secara optimal dengan fisiknya yang kuat. Shalat, puasa, zakat dan haji merupakan amalan di dalam Islam yang harus dilaksanakan dengan kondisi fisik yang sehat dan kuat. Apalagi berjihad di jalan Allah dan bentuk-bentuk perjuangan lainnya.

Keenam, Mujahadatul Linafsihi (berjuang melawan hawa nafsu). Setiap manusia memiliki kecenderungan pada yang baik dan yang buruk. Melaksanakan kecenderungan pada yang baik dan menghindari yang buruk amat menuntut adanya kesungguhan. Kesungguhan itu akan ada manakala seseorang berjuang dalam melawan hawa nafsu. Hawa nafsu yang ada pada setiap diri manusia harus diupayakan tunduk pada ajaran Islam

Ketujuh, Harishun Ala Waqtihi (disiplin menggunakan waktu). Setiap muslim amat dituntut untuk disiplin mengelola waktunya dengan baik sehingga waktu berlalu dengan penggunaan yang efektif, tak ada yang sia-sia. Kedelapan, Munazhzhamun fi Syuunihi (teratur dalam suatu urusan). Segala urusan mesti dikerjakan oleh seorang muslim secara profesional. Apapun yang dikerjakan, profesionalisme harus selalu diperhatikan. Kesembilan, Qodirun Alal Kasbi (memiliki kemampuan usaha sendiri/mandiri). Ini merupakan sesuatu yang amat diperlukan. Mempertahankan kebenaran dan berjuang menegakkannya baru bisa dilaksanakan manakala seseorang memiliki kemandirian terutama dari segi ekonomi. Tak sedikit seseorang mengorbankan prinsip yang telah dianutnya karena tidak memiliki kemandirian dari segi ekonomi. Kesepuluh, Nafi'un Lighoirihi (bermanfaat bagi orang lain). Manfaat yang dimaksud disini adalah manfaat yang baik sehingga dimanapun dia berada, orang disekitarnya merasakan keberadaannya.

Dari uraian ini dapat dipahami rincian unsur kepribadian yang harus dipenuhi agar seseorang memiliki Kepribadian Muslim, yaitu unsur fisik, keyakinan, ibadah, 


\section{Pembentukan Kepribadian Muslim Dengan Tarbiyah Islamiyah Saifurrahman}

akhlak, wawasan, ekonomi, pengendalian nafsu, menjaga waktu, manajemen urusan, dan unsur manfaat bagi sesama. Dan kesemuanya ini harus sesuai dengan nilai-nilai Islam.

\section{Internalisasi Nilai dalam Pembentukan Kepribadian Muslim}

Kepribadian, sebagaimana telah dijelaskan sebelumnya, merupakan hasil perpaduan dari berbagai faktor yang saling terkait antara yang satu dengan yang lainnya, yang mempengaruhi dirinya. Faktor tersebut terdiri dari faktor dari dalam diri dan faktor dari luar.

Internalisasi nilai-nilai Islam ke dalam pribadi seseorang, dapat dilakukan melalui dua cara. Pertama, dilakukan oleh dirinya sendiri (self education). Hal ini bertumpu pada proses natural pada manusia sendiri, karena manusia mempunyai kapasitas natural untuk belajar sendiri. Kedua, melalui orang lain (education by another). Hal ini berproses melalui kerjasama dengan orang lain. Dalam proses ini stimulasi dari orang lain diperlukan untuk mendorongnya melakukan kegiatan belajar (Arifin 2003, hlm. 156). Dua cara ini dalam dunia pendidikan Islam juga disebut dengan istilah Tarbiyah Dzatiyah (pembentukan diri sendiri) dan Tarbiyah Jama'iyah (pembentukan kolektif) ( Al Aidan 2003).

Tarbiyah Dzatiyah adalah sejumlah sarana pembentukan yang diberikan oleh seseorang kepada dirinya, untuk membentuk Kepribadian Muslim, yang sempurna di seluruh sisinya (ilmiah, iman, akhlak, sosial, dan lain-lain) dan naik tinggi ke tingkatan kesempurnaan sebagai manusia. Atau dengan kata lain, Tarbiyah Dzatiyah ialah tarbiyah seseorang terhadap diri sendiri dengan dirinya sendiri Tarbiyah Jama'iyah adalah sejumlah sarana pembentukan yang dilakukan oleh seseorang bersama orang lain. Misalnya masjid, keluarga, sekolah, media informasi, persahabatan, tour, silaturrahim atau program-program lainnya (Al Aidan 2003).

Yang perlu diperhatikan juga dalam Pembentukan Kepribadian Muslim adalah adanya keseimbangan dalam berbagai unsur penciptaan yang ada di dalam diri manusia. Karena manusia tercipta dari tiga unsur, jasad, ruh dan akal, maka pola pembentukan harus menyentuh ketiga unsur tersebut, secara seimbang.

\section{Keniscayaan Pembentukan Kepribadian Muslim}

Pembentukan Kepribadian Muslim adalah suatu keniscayaan untuk mengatasi masalah ummat. Hasan Al Banna dalam Risalah Muktamar Kelima mengatakan:

Saya tidak mendapatkan cara terbaik untuk mengatasi masalah keumatan ini dan meraih apa yang kita cita-citakan atas mereka, selain pembentukan pribadi mukmin yang kamil, dan selanjutnya melakukan penataan potensi mereka di medan kerja operasional (Al-Banna 1997, hlm. 264)

Yusuf Qardhawi meletakkan pembentukan Kepribadian Muslim sebagai aspek pertama dalam pembaharuan agama. Pribadi-pribadi yang di dalam dirinya terhimpun keimanan yang mantap, pemahaman yang dalam dan persatuan yang kokoh akan 
P-ISSN : 2541-3686

menjadi pelopor Islam, yang secara integral dan kooperatif mampu memimpin masyarakat kontemporer dengan ajaran Islam tanpa pamrih, dan mampu mengobati penyakit umat dari apotik Islam itu sendiri (Qardhawi 1993, hlm. 11).

Pembentukan Kepribadian Muslim merupakan langkah paling awal yang harus dilakukan dalam dalam perbaikan ummat Islam, sebelum melengkah ke tahap selanjutnya. Prayitno (2002, hlm. 3) mengatakan bahwa hal utama yang mesti dilakukan oleh umat Islam pada saat ini adalah berupaya semaksimal mungkin kembali kepada ajaran Islam, yang dimulai dari diri sendiri, keluarga dan selanjutnya adalah terbentuknya masyarakat yang islami.

\section{Konsep Tarbiyah Islamiyah dalam Pembentukan Kepribadian Muslim}

Konsep, dalam bahasa Inggris concept bermakna pengertian atau pemikiran umum (Salim 1993, hlm. 80). Dalam bahasa Indonesia, konsep bermakna rancangan, pendapat (paham) atau rancangan yang telah ada dalam pikiran (Poerwadarminta 2003, hlm. 611). Dengan demikian konsep dapat diartikan sebagai pemikiran, pendapat atau rancangan yang ada dalam pikiran.

Tarbiyah Islamiyah menurut Mahmud (1999, hlm. 21) memiliki pengertian sebagai cara ideal dalam berinteraksi dengan fitrah manusia, baik secara langsung (dengan katakata) maupun secara tidak langsung (dengan keteladanan dan sarana lain), untuk memproses perubahan dalam diri manusia menuju kondisi yang lebih baik. Konsep Tarbiyah Islamiyah berarti pemikiran, pendapat atau rancangan mengenai cara ideal dalam berinteraksi dengan fitrah manusia secara langsung atau tidak langsung untuk memproses perubahan dalam diri menuju kondisi yang lebih baik. Kondisi lebih baik yang dimaksud di sini adalah kepribadian muslim.

Dalam membentuk Kepribadian Muslim, konsep Tarbiyah Islamiyah memiliki sasaran dan tujuan, Sasaran tarbiyah untuk tingkat individu mencakup sepuluh poin. Yaitu:

1. Setiap individu dituntut untuk memiliki kelurusan akidah yang hanya dapat mereka peroleh melalui pemahaman terhadap al-Quran dan As-sunnah.

2. Setiap individu dituntut untuk beribadah sesuai dengan petunjuk yang disyariatkan kepada Rasulullah saw. Pada dasarnya, ibadah bukanlah hasil ijtihad seseorang karena ibadah itu tidak dapat diseimbangkan melalui penambahan, pengurangn atau penyesuaian dengan kondisi dan kemajuan zaman.

3. Setiap individu dituntut untuk memiliki ketangguhan akhlak sehingga mampu mengendalikan hawa nafsu dan syahwat.

4. Setiap individu dituntut untuk mampu menunjukkan potensi dan kreativitasnya dalam dunia kerja.

5. Setiap individu dituntut untuk memiliki keluasan wawasan. Artinya, dia harus memampu memanfaatkan setiap kesempatan untuk mengembangkan wawasan.

6. Setiap individu dituntut untuk memiliki kekuatan fisik melalui sarana-sarana yang dipersiapkan Islam. 


\section{Pembentukan Kepribadian Muslim Dengan Tarbiyah Islamiyah Saifurrahman}

7. Setiap individu dituntut untuk memerangi hawa nafsunya dan senantiasa mengokohkan diri di atas huikum-hukum Allah melalui ibadah dan amal saleh. Artinya, kita dituntut untuk berjihad melawan bujuk rayu setan yang menjerumuskan manusia pada kejahatan dan kebatilan.

8. Setiap individu dituntut untuk mampu mengatur segala lurusannya sesuai dengan keteraturan Islam. Pada dasarnya, setiap pekerjaan yang tidak teratur hanya akan berakhir pada kegagalan.

9. Setiap individu dituntut untuk mampu memelihara waktunya sehingga dia akan terhindar dari kelalaian dan perbuatan manusia. Dengan begitu, dia pun akan mampu menghargai waktu orang lain sehingga dia tidak memberikan kesempatan kepada orang lain untuk melakukan kesia-siaan, baik untuk kehidupan dunia maupun akheratnya. Tampaknya, tepat sekali apa yang dikatakan oleh ulama salaf bahwa waktu itu ibarat pedang. Jika tidak kita tebaskan dengan tepat, pedang itu akan menebas diri kita sendiri.

10. Setiap individu harus menjadikan dirinya bermanfaat bagi orang lain.

Untuk melihat keberhasilan tarbiyah dibuatlah kriteria-kriteria yang mengacu pada sepuluh sasaran di atas. Adapun tujuan Tarbiyah Islamiyah menurut Abdullah bin Ahmad Qadiri (1999), adalah membangun Kepribadian Muslim yang integral dari segala sisi-sisinya, khususnya sisi aqidah, ibadah, ilmu pengetahuan, budaya, akhlaq, perilaku, pergerakan, keorganisasian dan manajerial. Sehingga seluruh kegiatannya akan mengembangkan potensi ruhani, jasamani dan akal fikiran manusia. Tujuan akhir tarbiyah adalah menyiapkan seseorang untuk dapat memikul tanggung jawab da'wah dan menghadapi rintangan dalam da'wah (Raudhatul Jannah 2000A, hlm. 2).

\section{Simpulan}

Kepribadian Muslim merupakan sinergi antara pola-pola pikir, sikap dan prilaku seorang muslim yang dilandasi oleh akidah dan nilai-nilai Islam. Pembentukan Kepribadian Muslim adalah suatu usaha untuk membentuk kepribadian seseorang agar sesuai dengan aqidah dan nilai-nilai Islam.

Salah satu cara yang digunakan dalam Pembantukan Kepribadian Muslim adalah konsep Tarbiyah Islamiyah, yang merupakan pemikiran, pendapat atau rancangan mengenai cara ideal dalam berinteraksi dengan fitrah manusia secara langsung atau tidak langsung untuk memproses perubahan dalam dirinya menuju kondisi yang lebih baik. Konsep ini dijadikan sarana utama dan pertama dalam melakukan proses perubahan, karena secara operasional meliputi aspek penjagaan, perbaikan, penumbuhan dan pembinaan. Melibatkan diri sendiri dan orang-orang lain. Meliputi aspek akal, fisik dan ruh.

Sasarannya adalah individu yang memiliki kelurusan akidah; beribadah sesuai dengan petunjuk Rasulullah saw; memiliki ketangguhan akhlak; mampu menunjukkan potensi dan kreativitasnya dalam dunia kerja; memiliki keluasan wawasan; memiliki 
RAUDHAH Proud To Be Professionals qurnal Tarbiyakndamiyah

Volume 1 Nomor 1 Edisi Juni 2016

P-ISSN : 2541-3686

kekuatan fisik; memerangi hawa nafsunya; mampu mengatur segala urusannya; mampu memelihara waktunya; dan menjadikan dirinya bermanfaat bagi orang lain.

\section{DAFTAR PUSTAKA}

Al Quran Al Karim 1983. Daar Ibnu Katsir, Damaskus

Abraham, Amit 2005. Mengupas Kepribadian Anda. Terjemahan oleh Anindito Aditomo, BIP, Jakarta

Al Aidan, Abdullah 2003. Tarbiyah Dzatiyah. An Nadwah, Jakarta

Al-Banna, Hasan 1992. Majmu'ah Rasail. Daru At Taujii' Wa An Nasyr Al islamiyah, Kairo

Arifin, Muzayyin 2003. Filsafat Pendidikan Islam. Bumi Aksara, jakarta

Mahmud, Ali Abdul Halim 1999. Perangkat-Perangkat Tarbiyah Ikhwanul Muslimin. Intermedia, Jakarta

Prayitno, Irwan 2002A. Membentuk Kepribadian Muslim. Pustaka Tarbiatuna. Jakarta

----- 2002B. Membentuk Kepribadian Da'i. Pustaka Tarbiatuna. Jakarta

Poerwadarminta, W.J.S. 2003. Kamus Umum Bahasa Indonesia. Balai Pustaka, Jakarta

Qardhawy, Yusuf 1993. Prioritas Gerakan Islam. Terjemahan Oleh A. Najiyulloh. Al Ishlahy Press, Jakarta

Raudhatul Jannah, Tim 2000A. Garis-Garis Besar Program Tarbiyah, buku A. Kelompok Kajian Manhaj Tarbiyah, Jakarta

Salim, Peter 1993. Practical English-Indonesian Dictionary. Modern English Press, Jakarta

Sujanto, Agus 1996. Psikologi Perkembangan. Rineka Cipta, Jakarta

Suryabrata, Sumadi 2002. Psikologi Kepribadian. Raja Grafindo Persada, Jakarta

Uhbiyati, Nur 1998. Ilmu Pendidikan Islam. Pustaka Setia, Bandung

Adin 2007. Mengenal Empat Tipe Kepribadian http://www.fkmi.org/new/?q=artikel/2007/09/28/mengenal-empat-tipekepribadian. Di-download pada tanggal 4 juli 2008

Dakwatuna.com, Tim $2007 . \quad$ Kepribadian Muslim. http://www.dakwatuna.com/2007/kepribadian-muslim/. Di-download pada tanggal 4 juli 2008

Firdaus, Yulian 2007. Personality Disorder. http://yulian.firdaus.or.id/2007/05/05/personality-disorder/. Di-download pada tanggal 20 Agustus 2008 
Pembentukan Kepribadian Muslim Dengan Tarbiyah Islamiyah

Saifurrahman

Fuad, Ibnu 2006. Apakah Anda Berkepribadian Muslim?. http://hidayatullah.com/index.php?option=com joomlaboard\&Itemid=79\&func=vi ew\&id=18135\&catid=16. Di-download pada tanggal 20 Agustus 2008

Gunadi 2008. Kepribadian. http://www.sabda.org/publikasi/e-konsel/047/. Di-download pada tanggal 26 Juli 2008

Husna 2007. Islam Dan Jalan Pemberantasan Narkoba. http://www.waspada.co.id/Opini/Artikel/Islam-Dan-Jalan-PemberantasanNarkoba.html. Di-download pada tanggal 10 juli 2008

Matta, Anis 2008. Membentuk Karakter Muslim. http://ansharjalante.multiply.com/journal/item/45. Di-download pada tanggal 10 juli 2008

Mubarok, Achmad 2007. Membangun Kepribadian Muslim. http://mubarokinstitute.blogspot.com/2007 0301 archive.html. Di-download pada tanggal 10 juli 2008

Rab, Tabrani 2008. Kepribadian Melayu.

http://melayuonline.com/article/?a=TkpxL3FMZVZBUkU4Ng\%3D\%3D\%3D\&lan

g=Indonesia. Di-download pada tanggal 10 juli 2008

RBP 2008. Kepribadian. http://rumahbelajarpsikologi.com/index.php/kepribadian.html. Di download pada tanggal 15 Juli 2008 